\title{
Inheritance of Rust Resistance, Yield Performance in Irrigated Condition and Identification of High Yielding Rust Resistant Recombinant Inbred Lines in Lentil
}

\author{
Alok Kumar* and Ranjit Kaur Gill \\ Department of Plant Breeding and Genetics, Punjab Agricultural University (PAU), \\ Ludhiana 141004, India \\ *Corresponding author
}

Keywords

Inheritance,

variance, Lentil,

RILs, Rust

resistance

Article Info

Accepted:

18 January 2020

Available Online:

10 February 2020

\section{A B S T R A C T}

Lentil (Lens culinaris Medik subsp. culinaris) is an autogamous diploid $(2 n=2 x=14)$, cool season food legume crop cultivated globally. Genomic resources in lentil are limited in comparison with other food legumes, primarily due to large genome size and lack of genetic variation. The present study was aimed to evaluate a set of recombinant inbred lines (RILs) derived from L9-12 × FLIP 2004-7L under irrigated condition and to identify the high yielding rust resistant recombinant inbred lines in lentil. The inheritance of resistance to rust was examined in F1, F2 and RIL (F8) population of a cross involving a rust resistant exotic line FLIP2004-7L and a susceptible well adapted Indian cultivar L9-12. The results of genetic analysis of F1 and F2 showed that a single recessive gene controls rust resistance in lentil. This was further confirmed by the segregation pattern in the RIL population. A few high yielding rust resistant RILs were also identified. Other highly rust resistant lines may be used as donors in rust breeding programmes of lentil.

\section{Introduction}

Lentil (Lens culinaris ssp. culinaris Medik.) is an autogamous diploid $(2 \mathrm{n}=2 \mathrm{x}=14)$ species, believed to be originated in the Near East and later spread all through the Mediterranean Basin and Central Asia (Cubero et al., 2009). It is the fourth most important pulse crop grown in the world.
Globally, lentil is cultivated on 4.34 million hectares area with annual production of 4.95 million tons with an average yield of 1260 $\mathrm{kg} / \mathrm{ha}$ (FAOSTAT 2014). It is grown throughout West Asia and North Africa, the Indian subcontinent, North America, South America and Australia (Erskine, 1997). Major lentil producing countries in Asia are India, China, Syria, Iran and Bangladesh. India 
ranks first in lentil production and consumption, whereas Canada and Turkey are the world's largest lentil exporters. In India, it is usually grown after rainy season during winters with a production of 1.10 million tons from 1.80 million hectare area with productivity of $611 \mathrm{~kg} / \mathrm{ha}$ (FAOSTAT 2014). In Punjab, lentil occupied an area of 0.90 thousand hectares with a production of 0.63 thousand tons during 2014-15 (Anonymous 2014-15). It is an ancient, domesticated legume that has been nourishing humans for millennia (Sandhu and Singh, 2007). With $26 \%$ protein, lentil has the third highest level of protein from any plant-based food after soybeans and hemp and is an important part of diet in many parts of the world, especially in Indian subcontinent which have large vegetarian population. It is of high nutritional value and is consumed for its high levels of protein and micronutrients including iron, zinc and $\beta$-carotene (Erskine and Sarker, 2004). Its straw is also used as livestock feed and is a valued animal feed consisting of minerals and carbohydrates $2 \%$ and $59 \%$, respectively (Frederick et al., 2006). It is an important cool-season food legume crop generally grown in rotation with cereals to break cereal disease cycles and to fix atmospheric nitrogen, thus reducing the demand for nitrogen fertilizers (Anjam et al., 2005). The major reason for less area and low productivity of lentil as compared to other rabi crops is its susceptibility to biotic and abiotic stresses.

Among the biotic stresses, rust caused by Uromyces vicia fabae is an important foliar disease which is considered as a major limiting factor in successful lentil cultivation especially in north eastern and northern plains of India. The crop is attacked at all the stages of its growth but is more susceptible at flowering. Damage to the crop depends on the stage at which it is attacked, and yield losses ranging from 70 to $100 \%$ were observed under epidemic situations (Accatino, 1963; Sepulveda, 1985). The use of genetic resources possessing resistance may be the most effective strategy to control the disease. Generally, the Indian lentil germplasm lines possess low level of resistance to rust, whereas the exotic lines developed by International Centre for Agricultural Research in Dry Areas (ICARDA), Morocco have good level of resistance. Therefore, breeding for rust resistance using some exotic sources of resistance in hybridization programme for the transfer of resistance in the locally adapted cultivars or elite lines can be the most effective way to manage the disease on economical and sustainable basis. For the efficient transfer of resistance, information on nature and inheritance of resistance are the prerequisites. However, limited information about the genetics of rust resistance in lentil is available. Therefore, the present study was undertaken to determine the inheritance of rust resistance yield performance in irrigated condition and identification of high yielding rust resistant recombinant inbred lines in lentil

\section{Materials and Methods}

The present study was carried out at the experimental field area of Pulses Section, Department of Plant Breeding and Genetics, Punjab Agricultural University (PAU), Ludhiana and Regional Research Station, Gurdaspur (a hot- spot for rust) with objectives to evaluate the Inheritance of rust resistance, yield performance in irrigated condition and identification of high yielding rust resistant recombinant inbred lines.. Materials for the present study comprised of F1, F2 and a RIL population (F8) developed from a cross involving a rust susceptible parent L9-12 (female) and rust resistant line FLIP2004-7L. The RIL population was developed using single seed descent method. A set of 135 RILs (F8 ) along with parents 
and checks LL699 were grown at the experimental field area of Pulses Section, Department of Plant Breeding and Genetics, Punjab Agricultural University (PAU), Ludhiana for evaluation of yield performance study . while same material were grown at Regional Research Station, Gurdaspur (a hotspot for rust) during rabi 2013-14 in the field in paired rows of $1.5 \mathrm{~m}$ length in randomised block design with two replications The F1 and F2 generation of the same cross were planted in the field adjoining the RILs to record disease reaction. Disease severity was recorded on each line/plant using single digit $1-9$ scale by recording the percentage diseased area on leaves.

The plant were categorized as highly resistant (1 score), resistant (3 score), moderately susceptible (5 score), susceptible (7 score), and highly susceptible (9 score) following Khare et al., (1993). The F2 plants as well as RILs were classified into two classes, viz., resistant (which included highly- resistant and resistant plants) and susceptible (which included moderately susceptible, susceptible and highly susceptible plants) to work out the inheritance. The 135 RILs along with parents were evaluated during two consecutive years (2013- 14 and 2014-15) for yield performance at the experimental field area of Pulses Section, Department of Plant Breeding and Genetics, PAU, Ludhiana. The data of field experiments was statistically analyzed using an analysis of variance (ANOVA) (Kohout et al., 1981). All data analysis was carried out using SAS software (2003).

\section{Results and Discussion}

\section{Evaluation of yield of RILS in irrigated condition}

Analysis of variance (ANOVA) for the experimental design The 135 RILs along with parents and checks LL699 were evaluated during two consecutive years (2013- 14 and 2014-15) under Irrigated conditions. The material was planted in an alpha lattice design and analysis of variance was done using software; Model (GLM) procedure of SAS. Analysis of variance was performed for the morphological, yield and its attributing traits viz., days to $50 \%$ flowering, days to maturity, plant height, number of pods per plant, 100seed weight, seed diameter and seed yield per plot for individual year data and for the combined data during both years. The results indicated that the mean sum of squares of genotypes were highly significant for all the studied traits $(\mathrm{P}<0.001)$ which account for the genetic variability among the RILs, whereas blocks exhibited non-significant differences indicating homogeneity within blocks for individual year (Table 1 ). There was significant differences among the RILs s in each year and pooled analysis revealed non-significant year $\times$ RILs interaction. Characterization of RILs for various traits was done based on the pooled data.

\section{Mean performance and range of RILs for various traits in irrigated condition}

The mean values of RILs and parents for various morphological and yield attributing traits under irrigated conditions (Appendix-I)

Inheritance of resistance to lentil rust in a cross L9-12 x FLIP-2004-7L under natural field conditions

The data on reaction to rust of parents, $\mathrm{F}_{1}, \mathrm{~F}_{2}$ and $\mathrm{F}_{8}$ are given in Table 1 and 2. All the plants of female parent L9-12 showed susceptible reaction (score 7), whereas all the plants of male parent FLIP2004-7L gave resistant reaction (score 3) indicating that parents were genetically pure for the trait under study. All the eight $\mathrm{F}_{1}$ plants were susceptible (score 7) indicating that susceptibility is dominant to resistance. 
Table.1 Analysis of variance for different traits in RILs of lentil using alpha-lattice design under irrigated conditions

\section{Mean sum of squares}

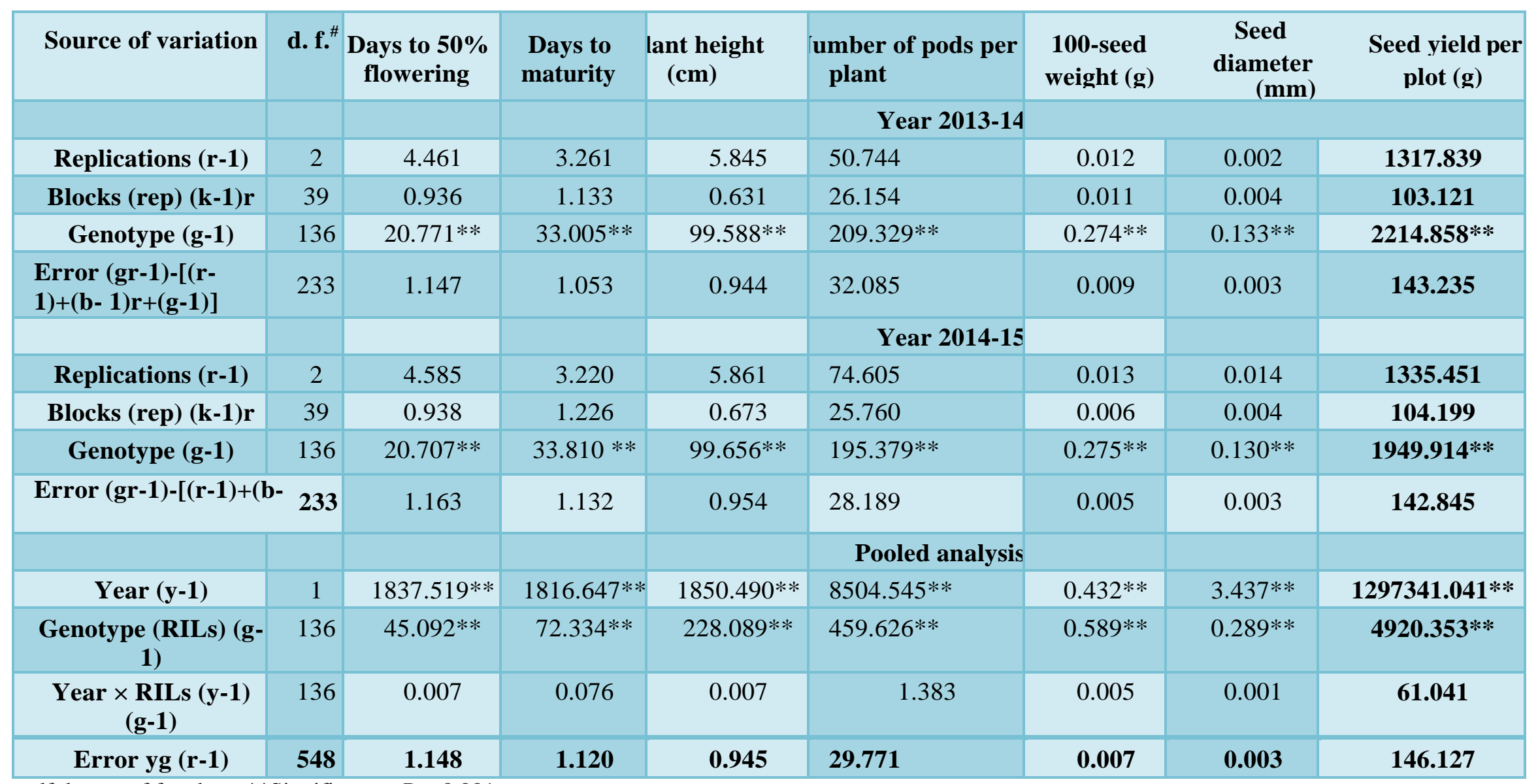

df degree of freedom; $* *$ Significant at $\mathrm{P}<0.001$ 
Table.2

\begin{tabular}{|l|l|l|l|l|}
\hline \multirow{2}{*}{ Trait/condition } & \multicolumn{4}{|c|}{ Irrigated condition } \\
\cline { 2 - 5 } & L9-12 & FLIP 2004-7L & RILs & Mean \\
\hline Days to 50\% flowering & 105 & 112 & $99-111$ & 106 \\
\hline Days to maturity & 146 & 157 & $140-156$ & 147 \\
\hline Plant height (cm) & 41 & 27 & $34-68$ & 47 \\
\hline Number of pods per plant & 53 & 29 & $36-78$ & 54 \\
\hline 100-seed weight (g) & 1.97 & 3.92 & $1.90-3.40$ & 2.3 \\
\hline Seed diameter (mm) & 3.28 & 4.31 & $3.20-4.31$ & 3.44 \\
\hline Seed yield per plot $(\mathbf{g})$ & 118.20 & 21.27 & $64.91-198$ & 122.88 \\
\hline
\end{tabular}

Table.2 Inheritance of resistance to lentil rust in a cross L9-12 x FLIP-2004-7L under natural epiphytotic field conditions

\begin{tabular}{|c|c|c|c|c|c|c|}
\hline Generation & $\begin{array}{c}\text { Susceptible } \\
\text { Plants/proge } \\
\text { nies }\end{array}$ & $\begin{array}{c}\text { Resistant } \\
\text { Plants/proge } \\
\text { nies }\end{array}$ & $\begin{array}{c}\text { Total } \\
\text { Plants/proge } \\
\text { nies }\end{array}$ & $\begin{array}{c}\text { Expected } \\
\text { ratio }\end{array}$ & $\sum \chi^{\mathbf{2}}$ & $\begin{array}{c}\text { Probabi } \\
\text { lity }\end{array}$ \\
\hline $\mathbf{F}_{\mathbf{1}}$ & 8 & 0 & 0 & - & - & - \\
\hline $\mathbf{F}_{\mathbf{2}}$ & 120 & 49 & 169 & $3 \mathrm{~S}^{*}: 1 \mathrm{R}^{*}$ & 1.289 & 0.256 \\
\hline $\mathbf{F}_{\mathbf{8}}$ & 77 & 58 & 135 & $1 \mathrm{~S}^{*}: 1 \mathrm{R}^{*}$ & 2.674 & 0.104 \\
\hline
\end{tabular}

*S: Susceptible; *R: Resistant

Table.3 List of promising lines identified for high seed yield and rust resistance

\begin{tabular}{|c|c|c|}
\hline RIL Number & Seed yield per plot (g) & Rust score \\
\hline RIL34 & 198 & 5 \\
\hline RIL77 & 177 & 3 \\
\hline RIL82 & 176 & 5 \\
\hline RIL90 & 182 & 3 \\
\hline RIL117 & 169 & 5 \\
\hline RIL127 & 172 & 1 \\
\hline Check LL699 & 148 & 7 \\
\hline CD (5\%) & 17.94 \\
\hline
\end{tabular}


The $\mathrm{F}_{2}$ population segregated into susceptible and resistant plants. Out of $169 \mathrm{~F}_{2}$ plants, 120 were susceptible and 49 were resistant and thus gave a good fit to the 3:1 ratio $\left(\chi^{2}=\right.$ 1.2893). These results showed that resistance to rust is controlled by a single recessive gene. These results were further corroborated with segregation pattern in RIL population derived from the same cross. Out of 135 RILs, 77 were susceptible and 58 were resistant and gave a good fit to the 1:1 ratio $\left(\chi^{2}=2.635\right)$. The results of the present study suggest that inheritance of rust resistance in lentil is simple and controlled by a single recessive gene, and can be easily incorporated into locally adapted high yielding elite lines through targeted hybridization program.

\section{Promising lines identified for high seed yield and rust resistance}

The list of some promising RILs possessing high yield and rust resistance is given in Table 3. A number of RILs showed yield advantage over the parents and some of them were also resistant to rust disease. Maximum seed yield per plot was recorded for RIL34 (198g) followed by RIL90 (182g), RIL77 (177g), RIL82 (176g), RIL117 (169g) and RIL127 (172g). Seed yield of these RILs was significantly higher than the best check LL699 (148g). Two RILs RIL90 and RIL77 possessing high degree of rust resistance (score 3) recorded 20 and 19.5 percent increase for seed yield over the best check LL699 (148) respectively. The highly resistant genotype RIL127 (score 1) showed 7.4 percent increase in seed yield over best check LL699.

Similar inheritance studies on lentil rust have been carried out by several workers, in which resistance is reported to be governed by one or two genes (monogenic or digenic inheritance) with different type of gene interaction. Sinha and Yadav (1989) observed the presence of monogenic dominant gene control of rust resistance in microsperma lentil. Similarly, Singh and Singh (1990) observed that rust resistance was found to be controlled by a single dominant gene in a cross involving microsperma resistant and susceptible lines. However, Lal et al., (1996) reported resistance was dominant in $\mathrm{F}_{1}$ generation and pattern of $\mathrm{F}_{2}$ segregation revealed segregation to be controlled by duplicate dominant genes in the cultivar Precoz. Mishra et al., (2008) also reported monogenic dominant control of resistance in lentil. However, Chahota et al., 2002 reported that resistance to rust is controlled by two duplicate non-allelic and non linked dominant genes. The variance in results is due to the different genetic background of the material used.

Overall it can be concluded that inheritance of resistance to leaf rust depends upon parents used in a study. Different studies showed that resistance either dominant or recessive and further the number of genes governing resistance and type of gene action also varied. Resistance is reported to be governed by one or two genes with dominance or epistatic (duplicate) type of gene interactions in case of lentil. In the present study the average score of resistant parent was 3 and that of susceptible parent was 7. However many recombinant inbred lines with higher degree of resistance $(<3)$ were observed. This indicated the presence of some modifiers or minor genes with positive as well as negative effect as also reported earlier by Khan et al., (2010) for spot blotch disease in barley.

It is concluded, on compilation of field evaluation of 135 RILs, along with checks it was concluded that RILs-34, -77, - 82, -90 and -127 showed significantly high yield potential coupled with high rust resistance. These RILs have good scope for enhancing productivity in lentil under rust-prone 
environment as well as under optimum conditions. These statistically superior lines on the basis of overall mean performance for different traits could be exploited directly in future breeding programme(s) after further evaluation.

\section{References}

Accantio P (1963) Chemical control experiment on lentil rust. Agricultural technical, 23: 7-14

Anjam M S, Ali A, Iqbal S H M and Haqqani A M (2005) Evaluation and correlation of economically important traits in exotic germplasm of lentil. Int $\mathbf{J}$ Agri Biol 7(6): 959- 61.

Chahota R K, Gupta V P and Sharma S K (2002) Indian J Genet 62:226-30.

Cubero J I, Perez de la Vega M and Fratini R (2009) Origin, phylogeny, domestication and spread In: Erskine W, Muehlbauer F J, Sarker A and Sharma B (ed). The lentil: botany, production and use. Pp 13-33.

Erskine W (1997) Lessons for breeders from land races of lentil. Euphytica 93: 10712.

Erskine W and Sarker A (2004) Lentil. In: Corke $\mathrm{H}$ and Walker C E (ed) Encyclopedia of grain sciences pp 142 50. Elsevier, London, U K.

Frederick M, Cho S, Sarker A, McPhee K, Coyne C, Rajesh P and Ford P (2006) Application of biotechnology in breeding lentil for resistance to biotic and abiotic stress. Euphytica 147: 14965.

FAOSTAT 2014. Food and Agriculture
Organization of the United Nations (FAO) Statistical Databases, http://faostat.fao.org/.

Kohout F J, Norwood G J and Am J (1981) Interpretation of research data: Analysis of variance. Hosp Pharm 38: 96-104.

Khan H, Tomar S M S and Chowdhury S (2010) Inheritance studies on spot blotch of wheat caused by Bipolaris sorokiniana. Indian J Genet 70:229-33

Khare M N, Bayya D and Bhiwal S P S (1993) Selection methods for disease resistance in lentil. In, Singh K B and Saxena M C (Eds) Breeding for stem tolerance in cool season legumes, $\mathrm{Pp}$ 107-121. John Willey and Sons Chicketter, UK.

Lal C, Sharma S K, Chahota R K and Lal C (1996) Inheritance of rust resistance in lentil. Indian J Genet Pl Breed 56:35051

Mishra G P, Mishra S K, Tiwari S K and Kumar A (2008) Inheritance of lentil (Lens culinaris) resistance to rust. Indian J agric sci 78:994-6.

SAS (2003) SAS/STAT Software: changes and enhancement through release 6.11. SAS Inst. Inc., Cary, NC.

Sepulveda R P (1985) Effect of rust caused by Uromuces febae (Pers) de Bary on the yield of lentils. Agricultural technical, 45: 335-339

Singh K and Singh I S (1990) Genetics of rust resistance in lentil. Indian J Agri Sci. 62:337-38.

Sinha R P and Yadav B P (1989) Inheritance of resistance to rust in lentil. Lens Newsletter, 16: 41

\section{How to cite this article:}

Alok Kumar and Ranjit Kaur Gill. 2020. Inheritance of Rust Resistance, Yield Performance in Irrigated Condition and Identification of High Yielding Rust Resistant Recombinant Inbred Lines in Lentil. Int.J.Curr.Microbiol.App.Sci. 9(02): 2393-2399. doi: https://doi.org/10.20546/ijcmas.2020.902.272 